\title{
血液透析患者の大動脈ならびに心臓弁の石灰化に 影響を与える因子の検討
}

\author{
川端 研治*1 中 井滋*2 渡辺 竹志*3 江崎 真知子*4 \\ 木村 友佳理*1 伊與田辰一郎*1 太田 圭 洋*5 長 屋 敬*5 \\ 小川 洋 史*5 \\ 名古屋記念財団金山クリニック腎臓内科*1 名古屋大学医学部在宅管理医療部*2 \\ 名古屋記念財団金山クリニック臨床工学部*3 同看護部 ${ }^{* 4}$ 新生会第一病院腎臓内科*5
}

key words：カルシウム・リン代謝, 炭酸カルシウム処方量, 心臓弁の石灰化, 大動脈の石灰化

〈要旨〉

近年, 透析患者の心血管系の石灰化が患者の予後予測因子となるとの報告や, さらには, カルシウム (Ca) 含有 リン $(P)$ 吸着剤の過剩投与自体が透析患者の心血管系の石灰化を促進するとの報告がなされている．今回，われわ れは, $\mathrm{Ca} \cdot \mathrm{P}$ 代謝異常や炭酸 $\mathrm{Ca}$ 処方量などの治療内容が心血管系の石灰化に与える影響を検討するために, 当院血 液透析患者の腹部 CT にて大動脈石灰化指数（aortic calcification index：ACI）を，CT と同一日に施行された心臓 超音波検査で弁の石灰化の有無を評価した。これらが評価できた患者 101 名の検査前 48 週間の炭酸 Ca 処方量なら びに患者背景, 血清 $\mathrm{Ca}$ 濃度, $\mathrm{P}$ 濃度, $\mathrm{Ca} \cdot \mathrm{P}$ 積 $(\mathrm{Ca} \times \mathrm{P})$ などが $\mathrm{ACI}$ や弁の石灰化に及ぼす影響を検討した．重 回帰分析で $A C l$ を上昇させる因子は加齢 $(p<0.01)$, 高 $\mathrm{Ca}$ 血症 $(p<0.01)$, 弁の石灰化を有すること $(p<0.05)$ であり，弁の石灰化を有する群では有さない群に比較して透析歴が長く $(p<0.05), A C I \quad(p<0.01)$, 血清 $P$ 濃度 $(\mathrm{p}<0.05)$ ならびに $\mathrm{Ca} \times \mathrm{P}(\mathrm{p}<0.05)$ が高值であった．炭酸 $\mathrm{Ca}$ の処方量は，ACl ならびに弁の石灰化の有無に有 意な影響を与えていなかった。しかし，炭酸 $\mathrm{Ca}$ 処方量は，血清補正 $\mathrm{Ca}$ 濃度と正の相関 $(p<0.05)$ を示し，重回 帰分析の結果, Ca $\times P$ を上昇させる因子となっていた $(p<0.05)$.

今回の検討で, $\mathrm{Ca} \cdot \mathrm{P}$ 代謝異常は心血管系の石灰化に関与すること, 炭酸 $\mathrm{Ca}$ の過剰投与は, 高 $\mathrm{Ca}$ 血症を介して 透析患者の予後規定因子である $\mathrm{Ca} \times \mathrm{P}$ を上昇させる危険性が示された. 今後は, 最小限の炭酸 $\mathrm{Ca} て ゙$ 高 $\mathrm{P}$ 血症を治 療する必要があると考えられた。

\section{The factors affecting aortic and valvular calcification in hemodialysis patients}

Kenji Kawabata*1, Shigeru Nakai*2, Takeshi Watanabe*3, Machiko Ezaki*4, Yukari Kimura*1, Shinichirou lyoda*1, Yoshihiro Ota*5, Takashi Nagaya*5, Hiroshi Ogawa*5

Department of Nephrology, Nagoya Memorial Foundation, Kanayama Clinic*1; Department of In-Home Medicine, Nagoya Univercity School of Medicine*2 ; Department of Clinical Engineering, Nagoya Memorial Foundation, Kanayama Clinic*3 ; Department of Nursing, Nagoya Memorial Foundation, Kanayama Clinic $^{* 4}$; Department of Nephrology, Shinseikai-Daiichi Hospital ${ }^{* 5}$

Recently, it has been reported that cardiovascular calcification is a predictor of mortality in dialysis patients. It has also been reported that the use of calcium salts to correct hyperphosphatemia leads to progression of cardiovascular calcification in dialysis patients. To elucidate the parameters contributing to uremic cardiovascular calcification, in this cross-sectional study, we calculated the aortic calcification index (ACl) using computed tomography (CT) in 101 hemodialysis (HD) patients and examined the presence of cardiac valvular calcification (VC) using an echocardiogram obtained on the same day as CT. We also calculated the subscription dose of calcium carbonate per week $\left(\mathrm{CaCO}_{3}\right)$ and the mean values of parameters, which have been reported to affect cardiovascular calcification, such as serum calcium ( $\mathrm{Ca}$ ), and phosphate $(\mathrm{P})$ concentrations, $\mathrm{Ca} \times \mathrm{P}$ product

川端 研治 名古屋記念財団金山クリニック腎臓内科邓 $456-0012$ 名古屋市熱田区沢上 2-2-14

Kenji Kawabata Tel : 052-679-1700 Fax :052-679-1761 E-mail : kawabata@hospy.com

〔受付：平成 16 年 10 月 25 日, 受理: 平成 17 年 2 月 24 日〕 
$(\mathrm{C} a \times \mathrm{P})$ for 48 weeks before CT was performed. Multiple regression analysis selected age $(p<0.01), \mathrm{Ca}(\mathrm{p}<$ $0.01)$, and presence of $\mathrm{VC}(\mathrm{p}<0.05)$ as the significant predictors for the elevated $\mathrm{ACl}$. The presence of $\mathrm{VC}$ was associated with longer duration on HD $(p<0.05)$, higher $\mathrm{ACl}(\mathrm{p}<0.01), \mathrm{P}(\mathrm{p}<0.05)$, and $\mathrm{Ca} \times \mathrm{P}(\mathrm{p}<0.05)$. Multiple regression analysis selected $\mathrm{CaCO}_{3}(p<0.01)$ as a weak but significant predictor of elevated $\mathrm{Ca} \times \mathrm{P}$. These results have shown that we need to correct abnormalities in $\mathrm{Ca} \cdot \mathrm{P}$ metabolism to avoid the progression of uremic cardiovascular calcification and that we should subscribe calcium carbonate as carefully as possible to avoid the elevation of $\mathrm{Ca} \times \mathrm{P}$.

\section{緒言}

透析患者の動脈や心臓の弁膜の石灰化は腎機能正常 者に比べ早期から出現し，かつ高頻度に認められる合 併症である ${ }^{1 \sim 3)}$.この心血管系の石灰化が透析患者の総 死亡や心血管合併症による死亡の予測因子になること が報告されている4 6).

カルシウム $(\mathrm{Ca})$, リン $(\mathrm{P})$ ，副甲状腺ホルモン (PTH) などの $\mathrm{Ca} \cdot \mathrm{P}$ 代謝異常は，心血管系の石灰化 に影響3,7 9)を与え，かつ独立した透析患者の予後規定 因子 ${ }^{10 \sim 14)}$ となっている. 近年, 海外から高 $\mathrm{P}$ 血症を是 正するために処方してきた $\mathrm{Ca}$ 含有 $\mathrm{P}$ 吸着剤自体が透 析患者の心血管系の石灰化を促進するとの報告 ${ }^{3,7,15)}$ なされ，K/DOQI ガイドライン ${ }^{16)}$ ではリン吸着阂中の $\mathrm{Ca}$ として 1,500 mg/日を超えるべきではない, との勧 告がなされるに至った.

今回, われわれは, $\mathrm{Ca} \cdot \mathrm{P}$ 代謝異常や炭酸 $\mathrm{Ca}$ 処方量 などの治療内容が心血管系の石灰化に与える影響を検 討するために，当院血液透析 (HD) 患者の腹部 CT に て大動脈石灰化指数 (aortic calcification index : $\mathrm{ACI})^{17)}$ を算出し，心臓超音波検査 (UCG) ${ }^{6 \sim 8)}$ で弁の石 灰化の有無を評価した。これらが評価できた患者の検 査前 48 週間の炭酸 $\mathrm{Ca}$ および活性型ビ夕ミン D の処 方量を算出し, これらの処方量ならびに患者背景, 血 清 $\mathrm{Ca}$ 濃度, $\mathrm{P}$ 濃度, $\mathrm{Ca} \cdot \mathrm{P}$ 積 $(\mathrm{Ca} \times \mathrm{P})$ 等が $\mathrm{ACI}$ や 弁の石灰化に及ぼす影響を検討した。

\section{I . 対象と方法}

当院へ通院し 2000 年 1 月から 2004 年 6 月までの期 間内の同一日に上下腹部 CT と UCG を受けた HD 患 者を研究対象とし, 各患者の検査前 48 週間を観察期間 とした. 悪性疾患や膠原病の診断が確定している患者, 観察期間中に副甲状腺摘出術（PTx）を受けた患者, ならびに透析液 $\mathrm{Ca}$ 濃度が変更になった患者は対象よ り除外した．また，CT と UCG 施行前に他院へ入院し ていた期間は観察期間から除外し，観察期間が 6 か月 未満の患者も対象より除外した。対象患者は 101 名で
あった。患者背景は, 男性 65 名, 女性 36 名で, 年歯 は $58.8 \pm 1.3$ 歳 $(29 \sim 84$ 歳) だった。原疾患に DM を 有するもの (DM 群) 15 名, DM を有さないもの (nonDM 群） 86 名であった。透析歴は，10.9 10.7 年 (1.0〜30.0 年) であった。観察期間中 $\mathrm{Ca}$ 濃度 3.0 $\mathrm{mEq} / \mathrm{L}$ の透析液（キンダリー $\mathrm{AF}-2$ 号：扶桑薬品工 業)で治療を受けていた患者 81 名, Ca 濃度 $2.5 \mathrm{mEq} /$ $\mathrm{L}$ の透析液 (キンダリーAF-3 号：扶桑薬品工業) で治 療を受けていた患者 20 名であった。

ACI は, 腹部単純 CT にて腹部大動脈の総腸骨動脈 分岐部直上のスライスより $9 \mathrm{~cm}$ の大動脈周囲を 12 分割し各スライスの石灰沈着の広がりを百分率で表し その平均值とした ${ }^{17)}$. 同一上下腹部 CT フィルムを用 い, 約 3 か月の間隔を置き 2 回 ACI を算出した. 2 回 の $\mathrm{ACI}$ 值の平均値を各患者の $\mathrm{ACI}$ 值とした. UCG で 臨床検査技師と循環器内科医がともに大動脈弁ならび に僧帽弁の石灰化ありと評価した症例を弁の石灰化を 有する症例とした。

検査前 48 週間の処方箋ならびにカルテより, 期間中 の炭酸 $\mathrm{Ca}$ ならびに $1 \alpha-(\mathrm{OH}) \mathrm{D}_{3}$ の処方量を求め, 1 週 間あたりの処方量を算出した. $1 \alpha-(\mathrm{OH}) \mathrm{D}_{3}$ の処方量 の算出は, 活性型ビタミン D 製剤を投与されていない 患者および観察期間中活性型ビタミン $\mathrm{D}$ 製剤として $1 \alpha-(\mathrm{OH}) \mathrm{D}_{3}$ のみを処方されていた患者 79 名を対象 に行った.

血清 $\mathrm{Ca}$ 濃度, 血清 $\mathrm{P}$ 濃度, 血清マグネシウム $(\mathrm{Mg})$ 濃度, 血清 CRP 濃度, 総コレステロール濃度（Tchol), 血清アルブミン濃度（Alb）ならびに血清アル カリフォスファターゼ (ALP) 濃度は観察期間中毎月 測定されていた．血清 Alb 濃度が $4.0 \mathrm{~g} / \mathrm{dL}$ 末満の場 合は，血清補正 $\mathrm{Ca}$ 濃度を $\mathrm{Ca}$ 濃度と $\mathrm{Alb}$ 濃度を用い, Payne ら ${ }^{18)}$ の補正式 (補正 $\mathrm{Ca}=\mathrm{Ca}+4-\mathrm{Alb}$ )にて算出 した. 補正 $\mathrm{Ca}$ 濃度と $\mathrm{P}$ 濃度の積を $\mathrm{Ca} \times \mathrm{P}$ とした。 以 上の測定項目の, 観察期間中の平均值を検討に用いた。 PTH 濃度は，高感度 PTH（HS-PTH，ヤマサ酱油） を用い年 2 回以上測定されており，これらの值の平均 值を検討に用いた。

結果は, 平均土標準誤差 $($ mean \pm S. E.) で表示した。 統計学的検討は, 対応のある 2 群間の比較は Wilcox- 
on singed-ranks test を, 対応のない 2 群間の比較は Mann-Whitney U test を用いた。 比率の差の検定は $\chi^{2}$ test を用いた．各因子間の関連は，単回帰分析を用 いPearsonの相関係数（R）を求め, 重回㷌分析を用 い標準化偏回帰係数 $(\beta)$ を求めた. $\mathrm{p}<0.05$ を有意差 ありとした。

\section{II. 結 果}

対象患者の ACI は, 一回目の測定では $39.6 \pm 3.2 \%$ $(0.0 \sim 100.0 \%), 2$ 回目の測定では $38.7 \pm 3.1 \%$ $(0.0 \sim 100.0 \%)$ だった. 両者の間に統計学的有意差は 認めなかった $(\mathrm{p}=0.14)$. 対象患者 101 例中 60 例 (59.4\%) に弁の石灰化を認めた。炭酸 $\mathrm{Ca}$ 処方量は $14.8 \pm 0.9 \mathrm{~g} /$ 週 $(0.0 \sim 42.0 \mathrm{~g} /$ 週 $), 1 \alpha-(\mathrm{OH}) \mathrm{D}_{3}$ 処方量 は $1.44 \pm 0.17 \mu \mathrm{g} /$ 週 $(0.0 \sim 8.31 \mu \mathrm{g} /$ 週 $)$ だった. 今回 の対象患者で観察期間内の血清 $\mathrm{P}$ 濃度が $6 \mathrm{mg} / \mathrm{dL}$ 以 上の患者は 101 名中 22 例 $(21.7 \%)$ のみで，対象患者 の血清 $\mathrm{P}$ 濃度の平均值は $5.4 \mathrm{mg} / \mathrm{dL}$ であり, $\mathrm{Ca} \times \mathrm{P}$ が55 (mg/dL $)^{2}$ を超える患者は 101 例中 31 名 (30.7\%) のみで, 対象患者の $\mathrm{Ca} \times \mathrm{P}$ の平均值は $51.0(\mathrm{mg} / \mathrm{dL})^{2}$ であった. また, 血清 HS-PTH 濃度が $\mathrm{PTx}$ の適応基準 ${ }^{19)}$ とされる $50 \mathrm{ng} / \mathrm{mL}$ を超える症例 は 101 例中 7 例 (6.9\%)のみで, 対象患者の血清 HS$\mathrm{PTH}$ 濃度の平均值は $18.4 \mathrm{ng} / \mathrm{mL}$ であった。

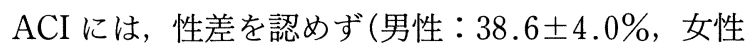
$41.5 \pm 5.3 \%, \mathrm{p}=0.63), \mathrm{DM}$ の有無でも有意差を認め

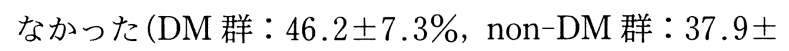
$3.6 \%, \mathrm{p}=0.35)$. ACI と各因子の単回帰分析の結果 (表 $1 \mathrm{~A}$ ) では $\mathrm{ACI}$ と年齢, 補正 $\mathrm{Ca}$ 濃度の間に正の相 関を認めた。重回帰分析の結果（表 $1 \mathrm{~B}$ ) においては, $\mathrm{ACI}$ を増加させる有意な説明変数となっていたもの は, 年歯, 補正 $\mathrm{Ca}$ 濃度, 弁の石灰化を有することで あった。

弁の石灰化を有する患者の比率に性差を認めなかつ た（男性：55.4\%, 女性：66.7\%, p=0.19). DM群 でnon-DM 群に比較して弁の石灰化を有する患者の 比率は高い傾向を示したが有意差には至らなかった (DM 群: 80.0\%, non-DM 群: 55.8\%, p=0.07). 弁 石灰化の有無と各因子の検討 (表 2) では, 弁の石灰化 を有する群で有さない群に比較して, 透析歴が有意に 長く, $\mathrm{ACI}$, 血清 $\mathrm{P}$ 濃度, ならびに $\mathrm{Ca} \times \mathrm{P}$ が有意に高 值だった。

対象患者のうち観察期間以前に 13 例が PTxをす でに受けていた。これらの患者の背景は, 男性 11 名, 女性 2 名で, 原疾患は全例で慢性系球体腎炎であった。
表 1 大動脈石灰化指数 $(\mathrm{ACI})$ と各因子の単回帰分 析の結果 (A) ならびに重回帰分析の結果 (B)

(A)

\begin{tabular}{crr}
\hline & $\mathrm{R}$ & \multicolumn{1}{c}{$\mathrm{p}$} \\
\hline Age (years) & 0.373 & $<0.01$ \\
\hline Duration on HD (years) & -0.031 & 0.39 \\
\hline Corrected $\mathrm{Ca}(\mathrm{mg} / \mathrm{dL})$ & 0.345 & $<0.05$ \\
\hline $\mathrm{P}(\mathrm{mg} / \mathrm{dL})$ & -0.100 & 0.19 \\
\hline $\mathrm{Ca} \times \mathrm{P}(\mathrm{mg} / \mathrm{dL})^{2}$ & 0.056 & 0.32 \\
\hline $\mathrm{HS}-\mathrm{PTH}(\mathrm{ng} / \mathrm{mL})$ & 0.083 & 0.39 \\
\hline $\mathrm{Mg}(\mathrm{mg} / \mathrm{dL})$ & -0.048 & 0.34 \\
\hline $\mathrm{CRP}(\mathrm{mg} / \mathrm{dL})$ & 0.026 & 0.41 \\
\hline $\mathrm{T}-\mathrm{chol}(\mathrm{mg} / \mathrm{dL})$ & 0.085 & 0.23 \\
\hline $\mathrm{Alb}(\mathrm{g} / \mathrm{dL})$ & -0.051 & 0.33 \\
\hline $\mathrm{ALP}(\mathrm{IU} / \mathrm{L})$ & 0.052 & 0.33 \\
\hline $\mathrm{CaCO}(\mathrm{g} / \mathrm{week})$ & -0.033 & 0.39 \\
\hline $1 \alpha-(\mathrm{OH}) \mathrm{D}_{3}(\mu \mathrm{g} /$ week $)$ & -0.031 & 0.39 \\
\hline
\end{tabular}

(B)

\begin{tabular}{ccc}
\hline & $\beta$ & $\mathrm{p}$ \\
\hline Age (years) & 0.386 & $<0.01$ \\
\hline Corrected Ca $(\mathrm{mg} / \mathrm{dL})$ & 0.224 & $<0.01$ \\
\hline $\mathrm{VC}$ & 0.182 & $<0.05$ \\
\hline
\end{tabular}

$\mathrm{R}$ : Pearson の相関係数, $\beta$ : 標準化偏回㷌係数, Corrected $\mathrm{Ca}$ : 血清補正 $\mathrm{Ca}$ 濃度, $\mathrm{CaCO}_{3}$ : 炭酸 $\mathrm{Ca}$ 処方量, $1 \alpha$ $(\mathrm{OH}) \mathrm{D}_{3}: 1 \alpha-(\mathrm{OH}) \mathrm{D}_{3}$ 処方量, VC : valvular calcification. 他の略号は本文中に記載.

PTx 施行群の透析導入から PTx を受けるまでの透 析期間は $14.7 \pm 1.6$ 年 $(5.0 \sim 24.0)$ で，透析導入から PTxまでの期間とACIには相関を認めなかった $(\mathrm{R}=0.27, \mathrm{p}=0.69)$. PTx 施行群と PTx 非施行群間 で各因子を比較した場合, 前者で後者に比較して透析 歴が有意に長く (PTx 施行群 : 19.3 1.8 年, PTx 非 施行群 : $9.6 \pm 0.7$ 年, $\mathrm{p}<0.01$ ), 補正 $\mathrm{Ca}$ 濃度 $(\mathrm{PTx}$ 施行群 : $9.0 \pm 0.2 \mathrm{mg} / \mathrm{dL}, \mathrm{PTx}$ 非施行群 $: 9.5 \pm 0.1$ $\mathrm{mg} / \mathrm{dL}, \mathrm{p}<0.05)$, ならびに HS-PTH 濃度 $(\mathrm{PTx}$ 施 行群: $6.4 \pm 1.2 \mathrm{ng} / \mathrm{mL}$, PTx 非施行群: $20.2 \pm 2.1$ $\mathrm{ng} / \mathrm{mL}, \mathrm{p}<0.01)$ が有意に低值であった. しかし, 両 群間に ACI ならびに弁の石灰化を有する患者の比率 には差がなかった。

炭酸 $\mathrm{Ca}$ 処方量と補正 $\mathrm{Ca}$ 濃度の間には, 弱いながら も有意な正の相関（ $\mathrm{R}=0.223, \mathrm{p}<0.05 ）$ を認めた. $\mathrm{Ca} \times \mathrm{P}$ と各因子の単回㷌分析(表 $3 \mathrm{~A}$ ) では, 血清 $\mathrm{P}$ 濃 度, 血清 HS-PTH 濃度, 炭酸 $\mathrm{Ca}$ 処方量 (図), 補正 $\mathrm{Ca}$ 濃度, $1 \alpha-(\mathrm{OH}) \mathrm{D}_{3}$ 処方量との間に有意な正の相関 を認めたが, 他の因子の影響を数学的に補正した重回 帰分析の結果 (表 $3 \mathrm{~B})$ では, $1 \alpha-(\mathrm{OH}) \mathrm{D}_{3}$ 処方量は有 
表 2 心臟弁の石灰化を有する群と有さない群間での各因子の比較

\begin{tabular}{cccr}
\hline & $\mathrm{VC}(+)$ & $\mathrm{VC}(-)$ & $\mathrm{p}$ \\
\hline Age (years) & $60.2 \pm 1.6$ & $56.7 \pm 2.1$ & 0.18 \\
\hline Duration on HD (years) & $11.9 \pm 0.9$ & $9.3 \pm 1.2$ & $<0.05$ \\
\hline $\mathrm{ACI}(\%)$ & $46.2 \pm 4.2$ & $28.8 \pm 4.7$ & $<0.01$ \\
\hline Corrected Ca (mg/dL) & $9.5 \pm 0.1$ & $9.4 \pm 0.1$ & 0.22 \\
\hline $\mathrm{P}(\mathrm{mg} / \mathrm{dL})$ & $5.6 \pm 0.1$ & $5.2 \pm 0.1$ & $<0.05$ \\
\hline $\mathrm{Ca} \times \mathrm{P}(\mathrm{mg} / \mathrm{dL})^{2}$ & $53.1 \pm 1.4$ & $48.1 \pm 1.3$ & $<0.05$ \\
\hline $\mathrm{HS}-\mathrm{PTH}(\mathrm{ng} / \mathrm{mL})$ & $20.3 \pm 2.7$ & $15.3 \pm 2.3$ & 0.13 \\
\hline $\mathrm{Mg}(\mathrm{mg} / \mathrm{dL})$ & $2.4 \pm 0.1$ & $2.4 \pm 0.1$ & 0.77 \\
\hline $\mathrm{CRP}(\mathrm{mg} / \mathrm{dL})$ & $0.40 \pm 0.11$ & $0.23 \pm 0.06$ & 0.36 \\
\hline $\mathrm{T}-\mathrm{chol}(\mathrm{mg} / \mathrm{dL})$ & $160.0 \pm 4.1$ & $170.5 \pm 4.7$ & 0.13 \\
\hline $\mathrm{Alb}(\mathrm{g} / \mathrm{dL})$ & $3.9 \pm 0.1$ & $3.9 \pm 0.1$ & 0.92 \\
\hline $\mathrm{ALP}(\mathrm{IU} / \mathrm{L})$ & $254.4 \pm 13.4$ & $222.4 \pm 11.5$ & 0.21 \\
\hline $\mathrm{CaCO}(\mathrm{g} / \mathrm{week})$ & $14.7 \pm 1.1$ & $15.3 \pm 1.6$ & 1.00 \\
\hline $1 \alpha-(\mathrm{OH}) \mathrm{D}_{3}(\mu \mathrm{g} /$ week $)$ & $1.64 \pm 0.29$ & $1.32 \pm 0.19$ & 0.85 \\
\hline
\end{tabular}

Corrected $\mathrm{Ca}$ : 血清補正 $\mathrm{Ca}$ 濃度, $\mathrm{CaCO}_{3}$ : 炭酸 $\mathrm{Ca}$ 処方量,

$1 \alpha-(\mathrm{OH}) \mathrm{D}_{3}: 1 \alpha-(\mathrm{OH}) \mathrm{D}_{3}$ 処方量, VC : valvular calcification.

他の略号は本文中に記載.

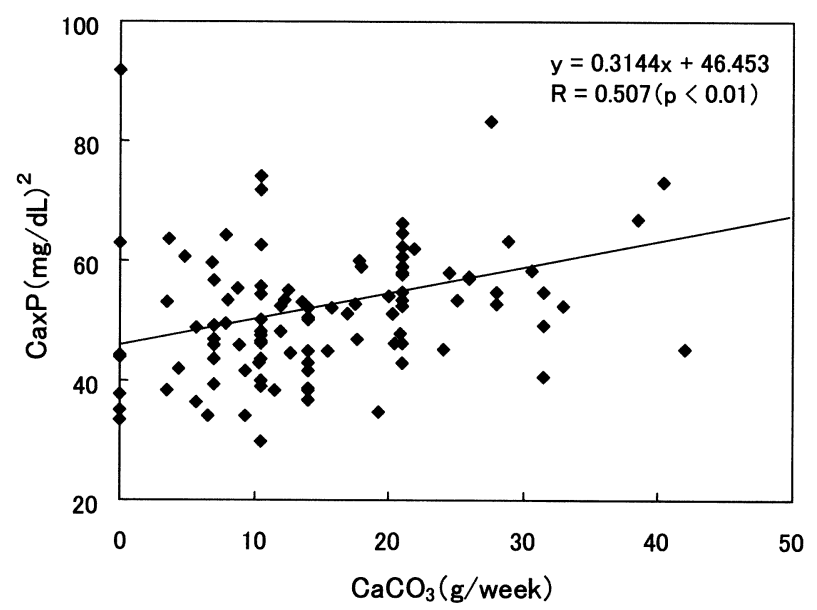

図 炭酸 $\mathrm{Ca}$ 処方量と $\mathrm{Ca} \times \mathrm{P}$ 積の相関

意な説明変数とはならず，炭酸 $\mathrm{Ca}$ 処方量は血清 $\mathrm{P}$ 濃 度の約 10 分の 1 程度だが, 血清 HS-PTH 濃度よりも 強くかつ統計学的に有意な説明変数となっていた。

\section{III. 考 察}

今回の検討で，重回帰分析の結果からは腹部大動脈 の石灰化の指標である ACI を上昇させる因子は年齢, 高 Ca 血症ならびに弁の石灰化を有することであっ た。加齢により動脈の石灰化が促進されるとする報 告1 3,5,7,8,11) はすでになされており, 今回の検討でも年 齢が ACI を上昇させる最も強い因子となっていた。し かし，多くの報告で動脈の石灰化の危険因子とされる
表 3 カルシウム・リン積と各因子の単回帰分析の 結果 $(\mathrm{A})$ ならびにカルシウム・リン積を目的 変数とした重回帰分析の結果 $(\mathrm{B})$

(A)

\begin{tabular}{|c|c|c|}
\hline & $\mathrm{R}$ & $\mathrm{p}$ \\
\hline $\mathrm{P}(\mathrm{mg} / \mathrm{dL})$ & 0.912 & $<0.01$ \\
\hline HS-PTH (ng/mL) & 0.418 & $<0.01$ \\
\hline $\mathrm{CaCO}_{3}$ (g/week) & 0.507 & $<0.01$ \\
\hline Corrected Ca (mg/dL) & 0.466 & $<0.01$ \\
\hline $1 \alpha-(\mathrm{OH}) \mathrm{D}_{3} \quad(\mu \mathrm{g} /$ week $)$ & 0.215 & $<0.05$ \\
\hline \multicolumn{3}{|l|}{ (B) } \\
\hline & $\beta$ & $\mathrm{p}$ \\
\hline $\mathrm{P}(\mathrm{mg} / \mathrm{dL})$ & 0.814 & $<0.01$ \\
\hline Corrected Ca $(\mathrm{mg} / \mathrm{dL})$ & 0.285 & $<0.01$ \\
\hline $\mathrm{CaCO}_{3}$ (g/week) & 0.09 & $<0.01$ \\
\hline HS-PTH (ng/mL) & 0.07 & $<0.05$ \\
\hline
\end{tabular}

$\mathrm{R}$ : Pearson の相関係数, $\beta$ : 標準化偏回帰係数, Corrected $\mathrm{Ca}$ : 血清補正 $\mathrm{Ca}$ 濃度, $\mathrm{CaCO}_{3}$ : 炭酸 $\mathrm{Ca}$ 処方量, $1 \alpha-(\mathrm{OH}) \mathrm{D}_{3}: 1 \alpha-(\mathrm{OH}) \mathrm{D}_{3}$ 処方量. 他の略号は本文中に 記載.

血清 $\mathrm{P}$ 濃度, $\mathrm{Ca} \times \mathrm{P}$ ならびに血清 HS-PTH 濃度が ACI を上昇させる因子になっていなかった. Braun ら ${ }^{1)}$ 電子ビーム CT で求めた HD 患者の冠動脈石灰 化指数に影響を与えている因子は年齢と高血圧のみで あったと報告している. Block らは, 彼らの総説20)の中 で, 観察期間以前の $\mathrm{Ca} \cdot \mathrm{P}$ 代謝異常の影響が観察期間 内のそれよりも強くBraun らの結果に反映されてい 
る可能性を指摘している。今回の検討においても Block ら ${ }^{20)}$ の指摘が適切である可能性はある.しかし, 今回の対象者の中で血清 $\mathrm{P}$ 濃度が, 1 年予後が悪化す るとされる $6 \mathrm{mg} / \mathrm{dL}$ 以上 ${ }^{10)}$ である患者や $\mathrm{Ca} \times \mathrm{P}$ が $\mathrm{K} / \mathrm{DOQI}$ ガイドライン ${ }^{16)}$ で示された $55(\mathrm{mg} / \mathrm{dL})^{2}$ を超 える患者の全体に占める割合は, Block ら ${ }^{12)}$ の報告し た米国の HD 患者の值に比べきわめて低い值を示し ている.このことが, ACI に血清 $\mathrm{P}$ 濃度と $\mathrm{Ca} \times \mathrm{P}$ が影 響を与えていなかった一因かもしれない. また，血清 HS-PTH 濃度に関しても PTx の適応基準 ${ }^{19)}$ とれ る $50 \mathrm{ng} / \mathrm{mL}$ を超える症例は全体の $6.9 \%$ みで, 血 清 HS-PTH 濃度の平均值が $18.4 \mathrm{ng} / \mathrm{mL}$ であったこ とから, 対象患者内に重症な二次性副甲状腺機能六進 症患者の占める比率が低かったことが, 血清 HS$\mathrm{PTH}$ 濃度が ACI や弁石灰化の有無に影響しなかっ た一因かもしれない.

一方，弁の石灰化の危険因子は透析歴が長いこと， ACI が高值であること, 血清 P 濃度が高いことならび に $\mathrm{Ca} \times \mathrm{P}$ が高值であることであった． ACI と弁の石 扊化の間には強い関連を認め, 動脈の石灰化と心臓の 弁の石灰化が密接に関連し進行することを示している と考えられた。しかし， $\mathrm{Ca} \cdot \mathrm{P}$ 代謝の指標では， ACI には補正 $\mathrm{Ca}$ 濃度のみが影響を与え，弁の石灰化には 血清 $\mathrm{P}$ 濃度と $\mathrm{Ca} \times \mathrm{P}$ が影響を与えていた。この結果 は, $\mathrm{Ca} \cdot \mathrm{P}$ 代謝異常が大動脈の石灰化と弁の石死化を 促進するメカニズムは若干異なることを示唆している のかもしれない.

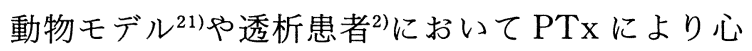
血管系の石灰化の進行が抑制されるとの報告がなされ ている. しかし, 今回の検討では, PTx の既往の有無 は ACI や弁の石灰化の有無に影響を与えていなかつ た。この原因として，Block ら ${ }^{20)}$ が指摘するように PTx をすでに受けている患者では PTx を必要とす るほどの $\mathrm{Ca} \cdot \mathrm{P}$ 代謝異常に曝されていた期間があっ たことを考慮しなければいけない，ただ，今回の検討 でPTxは，残存腺や再発を認めなければ，その後の PTH は低值に保て, 少なくとも高 Ca 血症の危険を低 減できていることが示された。

今回の検討結果においても, $\mathrm{Ca} \times \mathrm{P}$ の最も強力な規 定因子は血清 $\mathrm{P}$ 濃度であった ${ }^{22)}$. しかし, $\mathrm{Ca} \times \mathrm{P}$ と補 正 $\mathrm{Ca}$ 濃度の間にも正の相関関係があることから $\mathrm{HD}$ 患者の心血管系の石灰化を進行させないためには K/ DOQI ガイドライン ${ }^{16)}$ で示されたように補正 $\mathrm{Ca}$ 濃度 を臨床検査值の正常範囲内に維持しつつ高 $\mathrm{P}$ 血症を 治療する必要性が再認識された。 塩酸セベラマー ${ }^{23) か ゙ ~}$ 本邦で使用可能になるまで高 P 血症の治療に主とし
て用いられてきた炭酸 $\mathrm{Ca}$ などの $\mathrm{Ca}$ 含有 $\mathrm{P}$ 吸着剤の 過利投与が透析患者の心血管系の石灰化を促進してし まう危険性が指摘されている3 3 ,7,15). 今回の検討では, 炭 酸 $\mathrm{Ca}$ 処方量は, $\mathrm{ACI}$ にも弁の石灰化の有無にも統計 学的に有意な影響を与えていなかった。この理由とし ては対象患者の炭酸 $\mathrm{Ca}$ 処方量の平均が 1 日あたり約 $2.1 \mathrm{~g}$ で，海外の報告 ${ }^{3,15)}$ に比較して少量であったこと や処方量の調査であり，実際の内服量の調査ではない ことなどが考えられる.しかし, 炭酸 $\mathrm{Ca}$ 処方量が単回 帰分析で, 補正 Ca 濃度と相関し, 重回帰分析において 血清 $\mathrm{P}$ 濃度の 10 分の 1 程度であるが $\mathrm{Ca} \times \mathrm{P}$ を上昇 させる因子になっていたことは，2つの意味を持つと 考えられる. そのひとつは，今回の処方量調査が患者 の実際の内服量を反映していたこと，もうひとつは， 炭酸 $\mathrm{Ca}$ の過剒投与は本検討で大動脈石灰化の危険因 子となっていた高 $\mathrm{Ca}$ 血症を招き，透析患者の予後規 定因子である $\mathrm{Ca} \times \mathrm{P}^{12,13)}$ を昇させてしまうことが確 認されたことである.

今後は, 食事療法や透析療法による P の除去に積極 的に取り組み，さらには塩酸セベラマーとの併用によ り炭酸 $\mathrm{Ca}$ の処方量を最小限にとどめる努力が必要で あると考えられた。

\section{結 語}

今回の検討でも, HD 患者の大動脈の石灰化ならび に心臓弁の石灰化に高 $\mathrm{Ca}$ 血症, 高 $\mathrm{P}$ 血症ならびに $\mathrm{Ca} \times \mathrm{P}$ の高值が関与していることが再確認された. 高 $\mathrm{P}$ 血症治療のために処方してきた炭酸 $\mathrm{Ca}$ を過剰に投 与すると高 $\mathrm{Ca}$ 血症を介して $\mathrm{Ca} \times \mathrm{P}$ を上昇させるこ とが示され, 今後は, 最小限の炭酸 $\mathrm{Ca}$ で高 $\mathrm{P}$ 血症を治 療する必要があると考えられた。

\section{文献}

1) Braun J, Oldendorf M, Moshage W, Heidler $R$, Zeitler E, Luft FC : Electron beam computed tomography in the evaluation of cardiac calcifications in chronic dialysis patients. Am J Kidney Dis 27 : 394 401, 1996

2) Bommer J, Strohbeck E, Georich J, Bahner M, Zuna I : Arteriosclerosis in dialysis patients. Int $\mathrm{J}$ Artif Organs $19: 638-644,1996$

3) Goodman WG, Goldin J, Kuizon BD, Yoon C, Gales B, Sider D, Wang Y, Chung J, Emerick A, Greaser L, Elashoff RM, Salusky IB : Coronary-artery calcification in young adults with end-stage renal disease who are undergoing dialysis. N Engl J Med 
$342: 1478-1483,2000$

4) Blacher J, Guérin AP, Pannier B, Marchais SJ, London GM : Arterial calcifications, arterial stiffness, and cardiovascular risk in end-stage renal disease. Hypertension $38: 938-942,2001$

5) Raggi P, Boulay A, Chasan-Taber S, Amin N, Dillon M, Burke SK, Chertow GM : Cardiac calcification in adult hemodialysis patients. A link between end-stage renal disease and cardiovascular disease? J Am Coll Cardiol 39 : 695-701, 2002

6) Wang AYM, Wang M, Woo J, Lam CWK, Li PKT, Lui SF, Sanderson JE : Cardiac valve calcification as an important predictor for all-cause mortality and cardiovascular mortality in long-term peritoneal dialysis patients : A prospective study. J Am Soc Nephrol 14:159-168, 2003

7) Guérin AP, London GM, Marchais SJ, Metivier F : Arterial stiffening and vascular calcifications in end-stage renal disease. Nephrol Dial Transplant 15 : 1014-1021, 2000

8) Ribeiro S, Ramos A, Brandão A, Rebelo JR, Guerra A, Resina C, Vila-Lobos A, Carvalho F, Remédio F, Ribeiro $\mathrm{F}$ : Cardiac valve calcification in haemodialysis patients: Role of calcium-phosphate metabolism. Nephrol Dial Transplant 13:20372040, 1998

9) Rubel JR, Milford EL: The relationship between serum calcium and phosphate levels and cardiac valvular procedures in the hemodialysis population. Am J Kidney Dis 41：411-421, 2003

10）日本透析医学会統計調査委員会：わが国の慢性透析療 法の現況（1994 年 12 月 31 日現在）。透析会誌 $29: 1$ 22, 1996

11) Kato A, Takita $T$, Maruyama $Y$, Kumagai $H$, Hishida A : Impact of carotid atherosclerosis on long-term mortality in chronic hemodialysis patients. Kidney Int $64: 1472-1479,2003$

12) Block GA, Hulbert-Shearon TE, Levin NW, Port FK : Association of serum phosphorus and calcium $\times$ phosphorus product with mortality risk in chronic hemodialysis patients: A national study. Am J Kidney Dis 31 : 607-617, 1998

13) Ganesh SK, Stack AG, Levin NW, Hulbert-Shearon TE, Port FK : Association of elevated serum $\mathrm{PO}_{4}$, $\mathrm{Ca} \times \mathrm{PO}_{4}$ product, and parathyroid hormone with cardiac mortality risk in chronic hemodialysis patients. J Am Soc Nephrol 12 : 2131-2138, 2001

14) Block GA, Klassen PS, Lazarus JM, Ofsthun N, Lowrie EG, Chertow GM : Mineral metaborizum, mortality, and morbidity in maintenance hemodialysis. J Am Soc Nephrol 15 : 2208-2218, 2004

15) Chertow GM, Burke SK, Raggi P : Sevelamer attenuates the progression of coronary and aortic calcification in hemodialysis patients. Kidney Int 62 : 245-252, 2002

16) National Kidney Foundation:K/DOQI clinical practice guidelines for bone metabolism and disease in chronic kidney disease. Am J Kidney Dis 42 (Suppl 3) : S 1-S 202, 2003

17）横山啓太郎：石灰化に関する情報の解釈と管理。腎と 骨代謝 $17 ： 233-240 ， 2004$

18) Payne RB, Little AJ, Williams RB, Milner JR : Interpretation of serum calcium in patients with abnormal serum proteins. Br Med J 15:643-646, 1973

19）冨永芳博：副甲状腺摘出術と術後管理，透析骨病変 一新しい考え方 (黒川 清, 深川雅史編), p 172-181, 日本メディカルセンター, 東京, 1999

20) Block GA, Port FK : Re-evaluation of risks associated with hyperphosphatemia and hyperparathyroidism in dialysis patients : recommendations for a change in management. Am J Kidney Dis 35 : 1226-1237, 2000

21) Amman K, Törnig J, Flechtenmacher C, Nobokv A, Mall G, Ritz E : Blood-pressure-independent wall thickening of intramyocardial arterioles in experimental uraemia : evidence for a permissive action of PTH. Nephrol Dial Transplant $10: 2043-2048$, 1995

22) Shigematsu $T$, Kono $T$, Satoh K, Yokoyama K, Yoshida T, Hosoya T, Shirai K : Phosphate overload accelerates vascular calcium deposition in endstage renal disease patients. Nephrol Dial Transplant 18 (Suppl 3) : III 86-III 89, 2003

23) Slatopolsky EA, Burke SK, Dillon MA : RenaGel ${ }^{\circledR}$, a nonabsorbed calcium-and aluminum-free phosphate binder, lowers serum phosphorus and parathyroid hormone. Kidney Int 55 :299-307, 1999 